studies disease. Circulanon 1962:25:300-10.

10 Rennie L. Eirup B, McDowell F. Anerial bruits in cerebrovascubr disease. Neurology 1964;14:751-6.

11 Thompson JE, Kanchner MM, Austin DJ a ai. Carotid endarterectony for cerebrovascular insufficiency istroke: Follow up of 359 cases. Ann Surg $1966 ; 163: 751-63$.

12 DeWeese JA, Rub CG, Satran R, et al. Surgical treatment for occtusive disease of the carotid anter. Ann Surg 1968;168:85-94.

13 Zieglet DK, Zikeli T, Dick A, et al. Correbition of bruits over the carocid artery with angiographically demonstrated leswons. Nearolozy 1971;21:860-5.

If David TE, Humphries AW, Young JR, et al. A corretation of neck bruits and arterioscketoc anteries. Arch Surg 1973;107:729.31.

15 Gautict JC. Rosa A, L hermitte F. Auscuhation carotidicnne: Correbations chez 200 patients avec 332 angiographies. Reo Neurol (Pans; 1975;131: 175-84.

16 Leda K, Took JF, McHenry LC Jr. Carotid and vertebrobasibr transient ischemic attacks; clinical and angiographic corretation. Nearology 1979;-29. 10941101.

17 Wise G, Parker J, Burkholder J. Supraorbital Doppler studies, carotid bruits. and arteriography in unibteral ocular or cerebral ischaemic disorders. and arteriography in

18 Rikes TS, Lieberman A, Kopetman 1 a al Sympams, stenosis, and bruir: interretationships in carotid anery disease. Arch $S_{u r g} 1981 ; 116: 218-20$.

19 Pessin MS, Panis $W$, Praget RJ, el al. Auscultation of cervical and ocular bruits in extracranial carotid occlusive disease: a clinical and angiographic study. Stroke 1983;14:246-9.

20 Chambers BR, Norris JW. Clinical significance of asymptomatic neck bruits Neurology 1985;35:742-5.

21 Ingall TJ, Homer D, Whisnant JP, et al. Predictive value of carotid bruit for carotid atherosckerosis. Arch Neurol 1989;46:418-22.
22 Sandok $\mathrm{BA}$, Whisnant JP, Furbn AJ, et al . Carotid artery bruits. Prevalence urvey and differentral diagnosis. Mavo Clin Proc 1982;57:227-30.

23 Lewis BD, James M, Wetch TJ. Current applications of dupkex and color flow doppler ultrasound imaging: carotid and peripheral vascular syseem. Maryo Chin Proc 1989;64:1147-57.

24 Hankey GJ, Wartow CP, Sellar RJ. Cerebral angiographic risk in mild cerebrovascular discase. Stroke 1990;21:209-22.

25 Sandercock PAG. Asympromatic carntid stenosis: spare the knife. Br Med $\mathcal{J}$ 1987;294:1368-9.

26 Cetul RD, Whismant JP Carotid endanerectomy Aron Inem Med 1989,111: $660-70$.

7 Chambers BR, Norris JW. Outcome in patients with asympromatic neck bruits. Nex Engl J Med 1986;315:860-5.

28 Fletcher RH, Fletcher SW, Wagner EH. Clincal epudemology: the essentials. 2nd ed. Baltimore: Williams and $\mathbf{W}$ ilkins, 1988.

29 Morris JA, Gardner MJ. Cakulating confidence intervals for rebative risks, odds ratios, and standardised ratios and rates. In: Gardner M J, Atrman DG. Stanstics zouk confidemce. Belfast: Universities' Press, Br.Med J 1989-50-2.

30 British Medical Association Fees Worting Party: Prione consuluonts' twort: BMA gridelines London: BMA, 1989-45-6.

31 Warlow CP, Morris PJ. Introduction. In: Warlow CP, Morris PJ, eds. Transient ischaemic attacks. New York: Dekker, 1982:vii-xi.

32 Finkler SA. The distinction between cost and charges. Anen Intern Med 1982;96:102-9.

33 Bretand PM: Costing imaging procedures. Br $\mathcal{J}$ Radiol 1988:61:54-61.

34 Hankey GJ, Warlow CP, Motyneux AJ. Complications of cerebral angiography for parients with mild carorid terniory ischaemia being considered for carotid endartetectomy. I Neurol Neurosurg Psychiatry in press

35 Gibbs JM, Wise RJS, Leenders KL, Jones T. Evahuation of cerebral perfusio reserve in paticnts with carotid artery occhusion. Lancet 1984; i:310-4

Accepted 6.March 1990)

\title{
Human papillomaviruses in anogenital warts in children: typing by in situ hybridisation
}

\author{
A F Padel, V A Venning, M F Evans, A M Quantrill, K A Fleming
}

\section{Abstract}

Objective-To identify the types of human papillomaviruses found in anogenital warts in children and to relate these to clinical and social information.

Design-In situ hybridisation using biotin labelled DNA probes to 11 types of human papillomavirus was performed on biopsy specimens from 17 children with anogenital warts.

Setting-Nuffield department of pathology and the department of dermatology, Oxford.

Patients-Children in one group were referred by general practitioners or paediatricians to the dermatology department, where biopsies were performed. The other children were seen in four different hospitals, and biopsy specimens were submitted to the laboratory at the physician's or pathologist's request.

Results - Of the 17 biopsy specimens, 10 contained cells positive with a probe to a genital human papillomavirus type (types 6 or 11), while six were positive with a skin virus type (types 2 or 3 ). One was negative. The virus type present bore no relation to the site or appearance of the warts. The virus type did, however, appear to correlate with groups of children. Skin types were commoner in older children (over 4 years), in those with a relative who had skin warts, and in children with warts elsewhere; there was no relation with the child's sex and no suspicion of sexual abuse in these children. These circumstances suggested non-sexual transmission, such as autoinoculation. In contrast, genital types were commoner in girls, in children under 3 years, in children with relatives with genital warts, and in those with no warts elsewhere. Nevertheless, there was suspicion or evidence of sexual abuse in only half these children, suggesting that other routes of transmission-for example, perinatal-might have been implicated.

Conclusion-Anogenital warts in children may contain either skin or genital wart virus type. Although the type of human papillomavirus present may give some indication of the likely mode of transmission, this can be interpreted only in conjunction with all available clinical and social information. The type of virus does not provide proof of the presence or absence of sexual transmission.

\section{Introduction}

There has recently been a massive increase in the number of human papillomavirus types characterised by DNA technology, but some specific types are repeatedly found in certain sites and lesions. Thus in adults types 6 and 11 are found almost exclusively in anogenital warts, ${ }^{1-5}$ whereas types $1,2,3$, and 4 are found in skin warts. ${ }^{6}$ This finding, in conjunction with epidemiological evidence, indicates that human papillomavirus types 6 and 11 are venereally - that is, sexually-transmitted. By extrapolation, it has been suggested that anogenital warts in a child may also be sexually transmitted and thus provide grounds for suspecting sexual abuse.

In the United States there is therefore a tendency to start social and criminal investigations for possible sexual abuse in all children with anogenital warts, ${ }^{810}$ although this has not been advocated in Britain. "Some have, however, proposed that the identification of a genital human papillomavirus type in anogenital warts in a child would support the possibility of sexual transmission. "12 This assumes that the tissue distribution of human papillomavirus types in children is the same as in adults. Very little data exist to support this assumption and those data conflict. Three studies have reported a total of 23 patients under 13 years old. ${ }^{13-15}$ In 18 the anogenital warts contained one or more of the genital human papillomavirus types. In contrast, Fleming et al reported a boy of 5 years with human papillomavirus type 2 in both hand and perianal warts, ${ }^{16}$ and Androphy recently reported unpublished observations in which $25 \%$ of childhood anogenital warts contained type $2 .{ }^{7}$ Thus, the correlation of human papillomavirus type with anatomical site may 
not be as strong in children as in adults and anogenital warts in children may not necessarily be sexually transmitted. Further data are needed about the human papillomavirus types occurring in anogenital lesions and their relation to possible sexual abuse.

We studied biopsy specimens from 17 children with anogenital warts using in situ hybridisation with DNA probes complementary to both skin and genital human papillomavirus types to ascertain which types were present and at what frequency. We related this to clinical information to try to determine the routes of transmission that can occur.

\section{Patients and methods}

Patients-Twelve patients were seen in the dermatology department in Oxford and five in other hospitals. Material was submitted to us for in situ hybridisation at the physician's request. Of the 12 Oxford children, 10 were referred directly to the dermatology department because of the presence of genital warts. In nine of these a low index of suspicion of sexual abuse was based on the opinion of the general practitioner and health visitor, assessment by a paediatrician in five cases, and no isolation of venereal pathogens in vaginal, anal, and throat swabs. In one child sexual abuse was regarded as possible but could not be confirmed. One child was referred via the social services department and the paediatric department for treatment, having already been removed from her family because of encopresis and other behavioural disturbance and an admission of sexual abuse by the father. Another child was suspected of being abused, and his sister was in care because of previous sexual abuse. The other five children were seen in paediatric, dermatology, or gynaecology departments in other districts or regions. Sexual abuse was suspected in two but there was no evidence of abuse in the other three.

Methods-Biopsy specimens were placed in formalin and routinely processed and embedded in paraffin wax. Sections were stained with haematoxylin and eosin or were submitted for in situ hybridisation. The method for in situ hybridisation was non-isotopic using biotinylated probes labelled by nick translation and an avidin-alkaline phosphatase detection system as previously described. ${ }^{18 \times 20}$

Probes-These were double stranded DNA probes received as gifts (see acknowledgements). Each probe was cut with appropriate restriction enzymes. In each case the restriction enzyme pattern on gel electrophoresis corresponded with the published pattern. A negative control of pBR 322 was always used. A positive control was also always run with each test; this consisted either of a section of a skin wart known to contain human papillomavirus type 2 or the $\mathrm{Y}$ chromosome repeat sequence probe pHY 2.1 on male and female tissue sections."

\section{Results}

All the biopsy specimens showed histological features of viral warts with papillomatosis, acanthosis, and intermittent parakeratosis. Changes suggestive of human papillomavirus infection (binucleation, nuclear enlargement, and irregularity and clearing of cytoplasm) were patchy in all the lesions but dysplasia was not present in any case. Keratinisation was present in all of the lesions except two (cases 10 and 16).

The results are summarised in the table. There were six boys and 11 girls. Human papillomavirus types 6 or 11 were present in the warts from 10 children, three boys and seven girls. Human papillomavirus types 2 or 3 were present in six, three boys and three girls. The vulval warts in one child were negative (case 1), and in another girl the perianal warts were negative but were regressing at the time of biopsy whereas similar warts on her buttocks and hands contained human papillomavirus type 2 (case 2 ).

Of the 10 patients in whom human papillomavirus types 6 or 11 were present, seven were 3 years old or under. In contrast, human papillomavirus types 2 or 3 were found only in children aged 4 years or more (although the age of onset of the warts was less in two cases).

Lesions described as dry common warts and moist fleshy condylomas were found to contain either genital or skin human papillomaviruses. Thus the appearance of the anogenital warts did not correlate with the human papillomavirus type and nor did the site. There was, however, some relation between the human papillomavirus type found in the child's anogenital warts and the presence and site of warts in relatives. Hand warts were the commonest warts present in relatives (six cases) and in four of these cases the child's anogenital warts contained a skin type (type 2 or 3 ). In three cases a relative currently had genital warts. In two of these abuse was thought to be possible and the child's genital warts contained human papillomavirus type 6. In the other case the warts contained human papillomavirus type 3 , abuse was thought to be unlikely, and the child herself and other family members had plane warts elsewhere.

Clinical details of 17 children with anogenital warts, presence of warts in relatives, and type of human papillomavinus found

\begin{tabular}{|c|c|c|c|c|c|c|c|c|c|c|c|}
\hline \multirow[b]{2}{*}{ Case No } & \multirow[b]{2}{*}{ Sex } & \multicolumn{2}{|c|}{ Age (vears) } & \multicolumn{2}{|c|}{ Anogenital warts } & \multicolumn{2}{|c|}{ Site of warts } & \multicolumn{2}{|c|}{ Relatives with warts } & \multirow{2}{*}{$\begin{array}{l}\text { Suspicion } \\
\text { of abuse }\end{array}$} & \multirow{2}{*}{$\begin{array}{l}\text { Type of virus } \\
\text { in child }\end{array}$} \\
\hline & & Presentation & Onset & No & Appearance & Anogenital & Other & Relative & Site & & \\
\hline 1 & $\mathbf{F}$ & 9 & $8 \cdot 5$ & $>20$ & Moist, fleshy & Vulval & Foot & None & & No & Negative \\
\hline 2 & $\mathbf{F}$ & 7 & 4.5 & $>20$ & $\begin{array}{l}\text { Moist and } \\
\text { common }\end{array}$ & $\begin{array}{l}\text { Perianal } \\
\text { (buttock) }\end{array}$ & $\begin{array}{l}\text { Hand, foot } \\
\text { and buttock }\end{array}$ & Brother & Hand & No & Negative and 2 \\
\hline 3 & $\mathbf{M}$ & 9 & 4 & $>20$ & Moist & Perianal & None & None & & No & 2 \\
\hline 4 & $\mathbf{F}$ & 5 & 3 & & Common & Perianal & None & Mother & Hand & No & 2 \\
\hline 5 & $\mathbf{M}$ & 5 & 4 & $>20$ & Moist & Perianal & Hand and face & None & & No & 2 \\
\hline 6 & $\mathbf{M}$ & 7 & 1.5 & $>20$ & Fleshy mass & Perianal & None & Mother & Hand & No & 2 \\
\hline 7 & $\mathbf{F}$ & $6 \cdot 5$ & 6 & 6 & Plane & Vulval & Face and thigh & $\begin{array}{l}\text { All family } \\
\text { Father }\end{array}$ & $\begin{array}{l}\text { Plane warts } \\
\text { Genital }\end{array}$ & No & 3 \\
\hline 8 & $\mathbf{F}$ & 3 & 1 & 3 & Dry, common & Natal cleft & None & Aunt & Genital & Possible & 6 \\
\hline 9 & $\mathbf{F}$ & 3 & 3 & 11 & Moist & Perianal & None & Unknown & & Confirmed & 6 \\
\hline 10 & $\mathbf{F}$ & 1 & 0.5 & $>20$ & Fleshy mass & $\begin{array}{l}\text { Vu!val and } \\
\text { perineal }\end{array}$ & None & None & & No & 6 \\
\hline 11 & $\mathbf{M}$ & 3 & $2 \cdot 5$ & $>20$ & Dry & $\begin{array}{l}\text { Perianal and } \\
\text { scrotal }\end{array}$ & None & None & & Possible & 6 \\
\hline 12 & $\mathbf{F}$ & 8 & 8 & 12 & Dry, fleshy & $\begin{array}{l}\text { Vulval and } \\
\text { intravaginal }\end{array}$ & None & None & & No & 6 \\
\hline 13 & $\mathbf{F}$ & 7 & 7 & 3 & Moist & Vulval & None & $\begin{array}{l}\text { Mother (in past) } \\
\text { and partner }\end{array}$ & Genital & Possible & 6 \\
\hline 14 & $\mathbf{M}$ & 4 & 3 & 10 & Dry, common & $\begin{array}{l}\text { Perianal and } \\
\text { scrotal }\end{array}$ & None & Sister (in past) & Hand & Probable & 6 \\
\hline 15 & $\mathbf{M}$ & 3 & 3 & $>20$ & Dry & $\begin{array}{l}\text { Perianal and } \\
\text { perineal }\end{array}$ & None & None & & No & 6 \\
\hline 16 & $\mathbf{F}$ & 2 & 2 & 3 & Moist & Vulval & None & Mother (in past) & Genital & No & 11 \\
\hline 17 & $\mathbf{F}$ & 2 & 2 & 1 & Dry & Perianal & None & Father & Hand & No & 6 and 11 \\
\hline
\end{tabular}


In the children themselves warts were present in other than the anogenital area in four cases. The anogenital warts in two of these were negative for human papillomaviruses (cases 1 and 2), but in both of the others (cases 5 and 7) contained skin human papillomavirus types. One of the children (case 5) had the same virus type in his hand warts as in his anogenital warts, but none of the other lesions were tested. In case 2 the hand and buttock warts contained human papillomavirus type 2 , while the perianal wart was negative (but regressing at the time of biopsy). None of the children with genital human papillomavirus types had warts elsewhere.

The signal was strong in sections of all the biopsy specimens despite variation in the time of formalin fixation between two days and several weeks. Cross reactions were seen at low stringency $\left(\mathrm{Tm}-30^{\circ} \mathrm{C}\right.$ ) between probes for human papillomavirus 2 and 3 and between probes for human papillomavirus 6 and 11 and at medium stringency $\left(\mathrm{Tm}-17^{\circ} \mathrm{C}\right)$ between those for human papillomaviruses 6 and 11. In paraffin sections using DNA probes cross hybridisation is thought to be likely at higher stringency than under other conditions especially between types 6 and $11 . .^{22}$ At very high stringency $\left(\mathrm{Tm}-7^{\circ} \mathrm{C}\right)$ one human papillomavirus type probe alone remained positive, staining with the other human papillomavirus type probes being eliminated in all but one case.

\section{Discussion}

Three recent studies have reported genital human papillomavirus types $(6,11,16$, and 18$)$ in anogenital warts in children, ${ }^{13-15}$ which, by extrapolation from adults, supports the assumption that most of these warts are sexually transmitted. By contrast our study showed that such warts contained a human papillomavirus type usually associated with skin warts in six out of 17 cases, suggesting that non-venereal transmission may be common.

One explanation of the difference might be the range of probes that we used, since previous studies using in situ hybridisation to type human papillomaviruses in anogenital warts have tested only for the genital types. ${ }^{13}$ Indeed there have been few studies of human papillomavirus types in anogenital warts which have used both skin and genital type probes. ${ }^{315}$

Another explanation may be that the technique we used was incapable of accurately distinguishing between human papillomavirus types. The probes we used all conformed, however, to the published data on restriction enzyme patterns for the particular human papillomavirus type. Furthermore, positive and negative controls worked appropriately with each batch of staining, and hybridisation did not occur with both skin and genital human papillomavirus probes in the same specimen. We therefore think it unlikely that our technique failed to discriminate clearly between human papillomavirus types. This being so, it is clear that anogenital warts in children do not necessarily contain genital human papillomavirus types.

Our data suggest that clinical examination is poor at predicting the human papillomavirus type present. Thus while the plane warts in one case contained human papillomavirus type 3 (as expected), in all the other cases no correlation was found between clinical appearance and human papillomavirus type. Both moist and dry anogenital warts contained either skin or genital human papillomavirus types. We therefore suggest that it is unwise for a doctor seeing anogenital warts in a child to predict the human papillomavirus type on the basis of the site or appearance of the warts alone.

From our data we cannot deduce whether anogenital warts containing genital human papillomavirus types are sexually transmitted while those containing skin types are not. The number of cases in this study was small, but the results suggest the presence of two groups of children, one with anogenital warts containing skin human papillomavirus types and one with anogenital warts containing genital papillomavirus types. Warts containing skin types occurred in older children and equally in boys and girls and were associated with warts elsewhere on the child and with hand warts in relatives. There was no evidence or suspicion of sexual abuse. Thus skin human papillomavirus types occurred in circumstances favouring non-venereal transmission. Autoinoculation and normal close family contact are both possible routes of transmission. In contrast, children with anogenital warts containing genital human papillomavirus types were more likely to be girls, to be aged 3 years or under, and to have a relative with genital warts. Suspicion of sexual abuse was present in half. In none of these children were there warts elsewhere on the body. Thus some of the cases of anogenital warts containing genital human papillomaviruses occurred in circumstances favouring sexual transmission. Others, however, occurred in the absence of such evidence, and in view of the young age of many of these children perinatal transmission must be considered likely. It is widely accepted that laryngeal papillomas, which are caused by human papillomavirus type 11 , are transmitted during passage through the mother's infected birth canal. Laryngeal papillomas most commonly occur in children up to the age of 5 years. ${ }^{23-25}$ Thus, although the finding of a genital human papillomavirus type in anogenital warts in a child may support sexual transmission, it does not provide proof. Equally, the presence of a skin human papillomavirus type does not disprove sexual transmission since these have occasionally been reported in anogenital warts in adults, ${ }^{26}$ and transmission of skin human papillomaviruses could also occur from the hand of an adult during sexual abuse.

In conclusion, we agree with Oriel that the presence of anogenital warts in a child is by itself not a marker for sexual abuse." In contrast to previous published studies in children our results indicate that anogenital warts may contain either skin or genital human papillomavirus types. Typing of human papillomaviruses in anogenital warts in children may thus be helpful as part of the investigation, but the results must be interpreted only in conjunction with all available clinical and social information. The type of papillomavirus should not be regarded as providing definite evidence of either the presence or absence of sexual transmission.

We thank the clinicians and pathologists in other districts and regions who submitted cases to us for permission to report their cases. AFP and AMQ were supported by locally organised research grants from Oxford Regional Health Authority. KAF is partly supported by the Wellcome Trust. We also thank the following for gifts of the viral probes: $\mathrm{Dr} M$ S Campo, Wolfson Laboratory for Molecular Pathology, the Beatson Institute for Cancer Research, Glasgow, for human papillomavirus types $2,3,4,6,11$, and 18; $\mathrm{Dr} M$ Connor, Paterson Laboratories, Christie Hospital, Manchester, for human papillomavirus type 16; Dr A Lorincz, Molecular Diagnostics Research, Bethesda Research Laboraties, Gaithesburg, Maryland, USA, for human papillomavirus types 31 and 33; Dr R Ostrow, Institute of Human Genetics, University of Minnesota, Minneapolis, Minnesota 55455, USA, for human papillomavirus type 5; and Professor $\mathrm{H}$ Pfister, Institute of Clinical Virology, University of Erlangen-Nurnberg, Erlangen D-8520, Federal Republic of Germany, for human papillomavirus type 1 .

1 Wells M, Griffiths S, Lewis F, Bird C. Demonstration of human papillomavirus types in paraffin processed tissue from human anogenital lesions by in-situ DNA hybridisation. F Pathol 1987;152:77-82

2 Gissmann L, Boshart M, Durst M, Ikenberg H, Wagner D, zur Hausen H. 
Presence of human papillomavirus in genital tumours. $f$ Invest Dermato

3 Schneider PS, Krumholz BA, Topp WC, Steinberg BM, Abramson AL. Molecular heterogeneity of female genital wart (condylomata acuminata papillomaviruses. Int $\mathcal{f}$ Gynecol Pathol 1984;2:329-36.

4 Gross G, Ikenberg H, Gissmann L, Hagedorn M. Papillomavirus infection of the anogenital region: correlation between histology, clinical picture and virus type: proposal of a new nomenclature. I Invest Dermatol 1985; 85:147-52.

5 de Villiers E-M, Gissman L, zur Hausen H. Molecular cloning of viral DNA from human genital warts. 7 Virol 1981;40:932-5.

6 Orth G, Favre $M$, Croissant $O$. Characterization of a new type of human papillomavirus that causes skin warts. I Virol 1977;24:108-20.

7 Gissmann L, Pfister H, zur Hausen H. Human papilloma viruses (HPV): characterization of four different isolates. V'irology 1977;76:569-80.

8 Goldenring JM. Condylomata acuminata in the pediatric patient. $f \mathrm{rol}$ 1987;138:1259-60.

9 Bender ME. New concepts of condyloma acuminata in children. Arch Dermatol 986;122:1121-4

10 Goldenring JM. Condylomata acuminata in the evaluation of child sexua abuse. Arch Dermatol 1987;123:1265-6.

11 Oriel JD. Anogenital papillomavirus infection in children. $\mathrm{Br} \mathrm{Med} f$ 1988;296: 1484-5

12 Shelton TB, Jerkins GR, Noe HN. Condylomata acuminata in the pediatric patient. F Crol 1986;135:548-9.

13 Vallejos H, Del Mistro A, Kleinhaus S, Braunstein JD, Halwer M, Koss LG. Characterization of human papilloma virus types in condylomata acuminat in children by in situ hybridization. Lab Invest 1987:56:611-5.

14 Rock B, Naghashfar Z, Barnett N, Buscema J, Woodruff D J, Shah K. Genital tract papillomavirus infection in children. Arch Dermatol 1986;122:1129-32.

15 Benton EC, MacKinlay GA, Barr BB, Smith IW. Characterization of human papillomavirus DNA from genital warts in children. Br $\mathcal{J}$ Dermatol 1989;121(suppl 34):36.
16 Fleming $\mathrm{KA}$, Venning $\mathrm{V}$, Evans $\mathrm{M}$. DNA typing of genital warts and diagnosis of sexual abuse of children. Lancet 1987 ;ii:454.

17 Androphy EJ. Human papillomavirus: current concepts. Arch Dermatol 1989;125:683-5

18 Burns J, Redfern DRM, Esiri MM, McGee JO'D. Human and viral gene detection in routine paraffin embedded tissue by in situ hybridisation with biotinylated probes: viral localisation in herpes encephalitis. $\mathcal{f}$ Clin Patho 1986;39:1066-73

19 Porter HJ, Khong TY, Evans MF, Chan VT-W, Fleming KA. Parvovirus as a cause of hydrops fetalis: detection by in situ DNA hybridisation. $f$ Clin Pathol 1988;41:381-3.

20 Burns J, Graham AK, McGee JO'D. Non-isotopic detection of in situ nucleic acid in cervix: an updated protocol. 7 Clin Pathol 1988;41:897-9.

21 Burns J, Chan VT-W, Jonasson JA, Fleming KA, Taylor S, McGee JO'D. Sensitive system for visualising biotinylated DNA probes in situ: rapid sex determination of intact cells. F Clin Pathol 1985;38:1085-92.

22 Herrington CS, Graham AK, Burns J, McGee JO'D. The investigation of double infection of condylomata acuminata by human papillomaviruses using a double labelling technique. I Pathol 1989;157:171A

23 Bennett RS, Powell KR. Human papillomaviruses: associations between laryngeal papillomas and genital warts. Pediatr Infect Dis $\mathcal{f}$ 1987;6:229-32.

24 Cohen SR, Geller KA, Seltzer S, Thompson JW. Papilloma of the larynx and tracheobronchial tree in children: a retrospective study. Ann Otol Rhinol Laryngol 1980;89:487-503.

25 Gissmann L, Wolnik L, Ikenberg H, et al. Human papillomavirus types 6 and 11 DNA sequences in genital and laryngeal papiliomas and in some cervical cancers. Proc Natl Acad Sci USA 1983;80:560-3.

26 Krzyzek RA, Watts SL, Andersen DL, Faras AJ, Pass F. Anogenital warts contain several distinct species of Human Papillomavirus. F Virol 1980; 36:236-44.

(Accepted 9 March 1990)

\title{
Control of defecation in patients with spinal injuries by stimulation of sacral anterior nerve roots
}

\author{
R P MacDonagh, W M Sun, R Smallwood, D Forster, N W Read
}

Spinal Injuries Unit, Lodge Moor Hospital, Sheffield S10 4LH

R MacDonagh, FRCS, Medical Research Council research fellow

\section{Subdepartment of}

Gastrointestinal

Physiology and Nutrition,

Department of Medical

Physics, and Department of

Neurosurgery, Royal

Hallamshire Hospital,

Sheffield

W M Sun, MB, research fellow

R Smallwood, FIEE,

consultant medical physicist

D Forster, FRCS, consultant neurosurgeon

N W Read, FRCP, professor

Correspondence to: $\mathrm{Mr}$ MacDonagh.

BrMed f 1990;300:1494-7

\section{Abstract}

Objective-To observe the effects of stimulation of the sacral anterior roots on anorectal and low colonic pressures and to programme implanted stimulators to produce defecation.

Design-Prospective study of 12 consecutive patients.

Setting-Spinal injuries unit and university gastrointestinal physiology department.

Patients - 12 Patients with complete supraconal spinal cord lesions. Their injuries had been sustained at least two years before the study.

Interventions-A Brindley-Finetech intradural sacral anterior root stimulator was implanted in all patients. Three months postoperatively the stimulator settings were adusted after measurement of simultaneous anorectal and low colonic pressures.

Main outcome measures-Full defecation.

Results-Six patients achieved complete rectal evacuation of faeces using the implant and subsequently did not require manual help for defecation. For all but one of the patients the total time taken to complete defecation was reduced, and all were free from constipation, the most prevalent gastrointestinal symptom in patients with spinal injuries.

Conclusions-Sacral anterior root stimulators can be programmed to achieve complete unassisted defecation and can considerably improve the quality of life of patients with spinal injuries.

\section{Introduction}

Spinal cord injuries often occur in fairly young people, who have the prospect of an almost normal life expectancy but a considerably impaired quality of life. These patients not only experience severe dysfunction of voluntary movement but also have impaired bladder, bowel, and sexual function.

Urinary problems in patients with spinal cord injuries have been extensively studied, and with the advent of intermittent self catheterisation, ${ }^{1}$ electrical stimulation of the bladder, ${ }^{2}$ and advances in diagnostic techniques considerable improvements have been made in managing lower urinary tract and renal function. In contrast, the management of bowel disorders and, in particular, the intractable constipation that is so common in these patients has remained essentially unchanged over the past two decades.

The first sacral anterior root stimulator was implanted in a patient with a spinal injury in $1976 .{ }^{34}$ Since then roughly 300 patients throughout Europe have had such devices implanted, with much success in managing the neurogenic bladder. The stimulator was initially developed to improve bladder emptying, ${ }^{25}$ but as the parasympathetic and somatic nerves that supply the distal colon, anorectum, and anal sphincter are all derived from the same sacral spinal roots that are used for electromicturition it seemed likely that the stimulator could also be used to induce defecation in paraplegic patients. Little has been reported regarding the action of the stimulator on colorectal motility, ${ }^{6}$ and there are few reports of full evacuation with this technique. ${ }^{78}$

We report clinical and manometric data on 12 consecutive patients with spinal injuries who had sacral anterior root stimulators implanted.

\section{Patients and methods}

PATIENTS

We studied 12 consecutive patients (three women and nine men aged 21-49 (mean age 33)). All had received traumatic spinal injuries that had resulted in complete supraconal cord lesions (10 thoracic, two cervical). Sacral anterior root stimulators were not implanted in patients until at least two years after their injuries occurred to allow for any neurological recovery. The time since implantation ranged from three months to six years (mean time 26.3 months), and all patients included in the study were using the stimulator effectively to empty the bladder.

After surgery for implantation we assessed evidence 